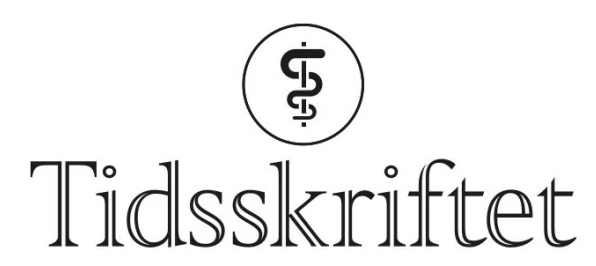

DEN NORSKE LEGEFORENING

\title{
Et langvarig covid-19-forløp hos en person med demens
}

KORT KASUISTIKK

\section{EIVIND AAKHUS}

eivind.aakhus@sykehuset-innlandet.no

Alderspsykiatrisk avdeling

Sykehuset Innlandet

Ottestad

Eivind Aakhus er ph.d. og avdelingsoverlege.

Forfatteren har fylt ut ICMJE-skjemaet og oppgir ingen interessekonflikter.

\section{ELENA H. FINBRÅTEN}

Alderspsykiatrisk avdeling

Sykehuset Innlandet

Ottestad

Elena H. Finbråten er assisterende enhetsleder.

Forfatteren har fylt ut ICMJE-skjemaet og oppgir ingen interessekonflikter.

\section{TRINE FINNES}

Medisinsk avdeling

Sykehuset Innlandet

Hamar

Trine Finnes er ph.d. og fungerende smittevernoverlege og assisterende direktør for medisin og helsefag.

Forfatteren har fylt ut ICMJE-skjemaet og oppgir ingen interessekonflikter.

\section{TINE SMEDSUND DONS}

Avdeling for medisinsk mikrobiologi

Sykehuset Innlandet

Lillehammer

Tine Smedsund Dons er avdelingsoverlege.

Forfatteren har fylt ut ICMJE-skjemaet og oppgir ingen interessekonflikter.

\section{TOM BORZA}

Alderspsykiatrisk avdeling

Sykehuset Innlandet

Ottestad

Tom Borza er ph.d. og seksjonsoverlege.

Forfatteren har fylt ut ICMJE-skjemaet og oppgir ingen interessekonflikter. 


\section{Vi presenterer en sykehistorie der en pasient med alvorlig demens og covid-19 hadde et langvarig og fluktuerende sykdomsforløp. PCR-tester for SARS-CoV-2 var vekslende positive og negative, noe som vanskeliggjorde diagnostikk og valg av isolasjonsregime.}

En mann i 6o-årene med alvorlig demens av Alzheimers type utviklet øvre luftveissymptomer med rennende nese og lett hoste. Noen måneder forut for dette var han blitt innlagt fra sykehjem til alderspsykiatrisk avdeling grunnet motorisk uro. Han hadde fra tidligere ingen hjerte- eller lungesykdommer. Dagen etter symptomdebut var han symptomfri. Han ble derfor ikke testet for SARS-CoV-2, da tilstanden ble oppfattet som vanlig forkjølelse. På grunn av residiv av symptomer og nyoppstått feber halvannen uke senere ble pasienten isolert og testet for SARS-CoV-2. Svaret forelå etter to dager og var positivt.

De neste ukene var pasienten sengeliggende. Etter to uker ble han oppfattet som preterminal på grunn av dyspné og betydelig generell svekkelse. Respiratorbehandling ble drøftet, men etter samtale med somatisk sykehus vurdert som ikke aktuelt.

Det videre sykdomsforløpet var fluktuerende. De dominerende luftveissymptomene var rennende nese, hoste og svelgevansker. Han hadde også tilbakevendende feber, særlig på ettermiddag og kveld. Etter flere uker utviklet han også atypiske symptomer, som påfallende bleke hender, rustfarget urin, hovne føtter samt oransjefargede hudflekker på over- og underekstremiteter og negler. Atferdsmessig var han i sine bedre perioder vandrende og urolig, og tidvis kunne det være utfordrende å opprettholde smittevernet. Selv flere uker ut i sykdomsforløpet var de beste dagene ikke som før sykdomsdebut. Det kliniske bildet, med fluktuasjoner i fysisk aktivitetsnivå og kognisjon, var vel forenlig med delirium.

Han ble testet med orofarynks/nasofarynksprøve for SARS-CoV-2 analysert med polymerasekjedereaksjonstest (PCR) flere ganger i sykdomsforløpet (henholdsvis dag 10, 40, 49, 62, 68 og 78). Til tider var korrekt prøvetaking utfordrende. Det var positive tester på den første og nest siste prøven, for øvrig var det negative prøveresultater. Første positive prøve hadde en lav syklusterskel (Ct)-verdi (19), mens andre og siste positive test hadde høy Ct-verdi (38). CRP var i hele forløpet lett forhøyet, med høyeste verdi (83 mg/l) etter to ukers sykdom. Differensialtelling av hvite blodceller viste normale funn eller kun helt lett forhøyet nivå uten åpenbar relasjon til sykdomsintensitet. Det var ingen mistanke om bakteriell superinfeksjon.

Bortsatt fra dagene da han ble oppfattet å være i preterminal fase, var næringsinntaket gjennomgående godt. Over to måneder etter symptomdebut hadde han siste feberdag. Deretter avtok også de øvrige symptomene. Pasienten var uten kliniske tegn på luftveissymptomer de neste syv dagene, og siste SARS-CoV-2-test tatt i dette tidsrommet var negativ. Isolering kunne da endelig oppheves.

\section{Diskusjon}

I denne sykehistorien hadde en pasient med alvorlig demens symptomer på covid-19 i totalt 70 dager. Prøver for påvisning av SARS-CoV-2 ble tatt på seks ulike tidspunkter i forløpet over en to måneders periode. På grunn av vedvarende lette luftveissymptomer, fluktuerende allmenntilstand og febertopper, var vi forsiktige med å oppheve isolasjon på tross av de første negative prøvene - en forsiktighet som ble støttet da det forelå en positiv prøve 68 dager etter symptomdebut. 
Utredning av covid-19 hos pasienter med alvorlig demens er utfordrende. Vi vurderte det som uhensiktsmessig og belastende for pasienten å bli sendt til somatisk sykehus for bildediagnostikk og videre utredning. Vår vurdering av pasientens smittsomhet var derfor basert på klinisk forløp og gjentakende PCR-målinger fra øvre luftveier.

PCR-undersøkelse av SARS-CoV-2 skiller ikke mellom intakt virus og rester av virus (1). Testen kan være positiv i flere uker etter gjennomgått infeksjon, og positiv test betyr ikke nødvendigvis at personen fremdeles er smittsom. Høy Ct-verdi, som vi så ved den siste positive prøven, kan indikere lav smittsomhet (2). Smitterisikoen antas å være størst omkring sykdomsdebut (3). Folkehelseinstituttet anbefaler at isolering i helseinstitusjon oppheves når pasienten er symptomfri og det enten foreligger to påfølgende negative PCRtester eller det har gått syv døgn fra symptomfrihet (3). På grunn av vedvarende symptomer var man derfor skeptisk til å oppheve isolasjonen. Symptomfrihet defineres av Folkehelseinstituttet som at vedkommende er tilbake i sin habituelle normaltilstand eller ikke lenger har de aktuelle symptomene. Hos den aktuelle pasienten tok det flere uker før han var i normaltilstanden igjen, og luftveissymptomene gjorde at man valgte å avvente med å oppheve isolasjon til ti uker etter sykdomsdebut. Muligheten for falskt negative PCRresultater er også til stede, spesielt ved lave virusmengder og problemer med adekvat prøvetaking, som kan være tilfelle hos pasienter med redusert samarbeidsevne.

Pasientens demenssykdom vanskeliggjorde symptomforståelsen på grunn av manglende samtykkekompetanse og evne til å formidle sykdomsopplevelse, vandring, motorisk uro og atypiske symptomer. Hvorvidt alle de atypiske symptomene var forårsaket av covid-19, kan vi ikke si. I tillegg ble forløpet komplisert av det vi oppfattet som delirium. Dette er en vanlig tilstand ved covid-19 hos pasienter med demens (4). Delirium har et svingende forløp, med ulike nevropsykiatriske symptomer. Det kan derfor ofte være vanskelig å skille delirium fra en klinisk forverring av demenssykdom. Utfordringene med smittevern og tilpasset mobilisering blir dermed forsterket.

Langvarige forløp av covid-19 er vanligst hos eldre (5). Helsevesenet bør være forberedt på at slike forløp er en stor belastning for både pasient, pårørende og personalgruppen. Til tross for at pasientene med covid-19 er mest smitteførende omkring sykdomsdebut, er det vanskelig å velge isolasjonsregime ved langvarige forl $\emptyset p$ hos eldre med demens. Smittevern kan være ekstra belastende for denne pasientgruppen, samtidig som det er hos de skjøreste man ser de mest alvorlige forløpene ( $\underline{6})$.

Pasientens pårørende har gitt samtykke til artikkelen blir publisert. Bruk av kliniske opplysninger er godkjent av Personvernombudet ved Sykehuset Innlandet (saksnummer 137313).

Artikkelen er fagfellevurdert.

\section{LITTERATUR}

1. Folkehelseinstituttet. Molekylær diagnostikk av Sars-Cov-2.

https://www.fhi.no/nettpub/coronavirus/testing-og-oppfolging-av-smittede/molekylar-diagnostikk/ Lest 23.8.2020.

2. Bullard J, Dust K, Funk D et al. Predicting infectious SARS-CoV-2 from diagnostic samples. Clin Infect Dis 2020; ciaa638. [PubMed][CrossRef]

3. Folkehelseinstituttet. Opphevelse av isolasjon ved covid-19.

https://www.fhi.no/nettpub/coronavirus/testing-og-oppfolging-av-smittede/opphevelse-av-isolasjon/ Lest 24.7.2020.

4. Rogers JP, Chesney E, Oliver D et al. Psychiatric and neuropsychiatric presentations associated with severe coronavirus infections: a systematic review and meta-analysis with comparison to the COVID19 pandemic. Lancet Psychiatry 2020; 7: 611-27. [PubMed][CrossRef]

5. COVID-19 Epidemiologisk trend og fokus: Symptomer. København: Statens serum institut, 2020. https://files.ssi.dk/COVID19-epi-trendogfokus-25052020-us12 Lest 15.6.2020. 
6. Hewitt J, Carter B, Vilches-Moraga A et al. The effect of frailty on survival in patients with COVID-19 (COPE): a multicentre, European, observational cohort study. Lancet Public Health 2020; 5: e444-51. [PubMed][CrossRef]

Publisert: 23. september 2020. Tidsskr Nor Legeforen. DOI: 10.4045/tidsskr.20.0566 Mottatt 29.6.2020, første revisjon innsendt 29.7.2020, godkjent 1.9.2020.

Publisert under åpen tilgang CC BY-ND. Lastet ned fra tidsskriftet.no 26. april 2023. 